Journal of Economics and Behavioral Studies (ISSN: 2220-6140)

Vol. 8, No. 3, pp. 26-40, June 2016

\title{
Monetary Policy Shocks and Industrial Sector Performance in South Africa
}

\author{
Adebayo Augustine Kutu, Harold Ngalawa \\ University of KwaZulu-Natal, Durban, Republic of South Africa \\ ade_kutu@yahoo.com
}

\begin{abstract}
This paper employs an eight variable Structural Vector Auto regression (SVAR) model to examine how monetary policy shocks affect industrial sector performance in South Africa using monthly data from 1994:1 to 2012:12.The study finds no direct link between exchange rate and interest rate shocks and industrial output growth. A money supply shock, however, is observed to exert a significant positive impact on industrial output growth from about the eighth month. The study also reveals that the interest rate response to an unanticipated increase in the rate of inflation is insignificant, reflecting the infrequent changes of the repo rate in the country. We also find evidence of a symbiotic relationship between industrial output growth and other sectors of the economy that form components of aggregate output. The study further demonstrates that monetary authorities have very limited control over industrial output growth using instruments of monetary policy. In addition, it is found that relatively large proportions of the variations in the rate of inflation are explained by changes in money supply, exchange rates and industrial output. We also observe that variations in exchange rates are largely explained by unexpected changes in the exchange rates themselves, which supports the Martingale Hypothesis of exchange rates.
\end{abstract}

Keywords: Monetary policy shocks, structural VARs, industrial sector performance

\section{Introduction}

While some studies have attributed the high unemployment rate (25.5\%) in South Africa to the country's low industrial sector performance (see Rodrik, 2008), other studies have shown that monetary policy can play a significant role in determining variations in output and prices, and consequently stimulating economic growth and a rise in employment (see Rafiq \& Mallick, 2008). The impact of monetary policy on industrial output as a component of aggregate output, however, remains a subject of continuing debate. The opinion that guides monetary authorities when there is a shock to the economy is that the monetary policy action taken in responding to such a shock may have short-term effects on growth, and long-term effects on inflation (Mihov, 2001). Consequently, there is an ongoing debate to decide on how best monetary authorities should respond to shocks that impact on the economy. The traditional transmission mechanism (in the short run) states that changes in monetary policy affect money supply, which changes interest rates to balance demand and supply. In turn, interest rate changes affect investment and consumption, which subsequently lead to a change in output and prices. This study, therefore, seeks to examine (i) the impact of monetary policy shocks on industrial sector performance (output), and (ii) how the shocks spread (propagate) over to selected variables in the economy.

In general, shocks are associated with a persistent decline or increase in output and commodity prices. The duration or continuous occurrence of a shock on a particular component is known as persistence of the shock, while its transmission effects through other variables is known as the spill over or propagation effect of that shock (Pedersen, 2011). The pressure and constraints of monetary policy resulting from global occurrences of unexpected or unpredictable events that can affect the economy, such as oil price shocks, exchange rate shocks and economic recessions, among others, lead to monetary policy shocks. According to Mountford and Uhlig (2009) monetary policy shocks entail an unanticipated upsurge in monetary policy instruments to control disturbances in the economy by the monetary authorities. Recently, the chronic unemployment crisis and an attempt to create millions of jobs have been at centre stage of South African policymakers' agendas. Various reforms have been undertaken. The New Growth Path document, for instance, targets the creation of 5 million jobs during the period 2015-2020, while the Industrial Policy Action Plan (IPAP 2) targets 350000 
new jobs in the manufacturing sector by 2020; and more interventions are planned, which will lead to 43000 direct jobs and 86000 indirect jobs, totalling 129000 jobs in the industrial sector (South African Government, 2010).

Further motivation for carrying out this study is rooted in the industrial revolution that has triggered permanent economic change in society. There has been a movement of labor from traditional activities in agriculture to a "modern" industrial sector in order to increase the economy's savings and investment rates and to foster economic growth (Rodrik, 2007). This movement to the industrial sector further provides a locus for stimulating the growth of other activities within the economy. In South Africa, out of a population of over 50 million, only 13.1 million are employed (2011 budget review). The agricultural sector accounts for $5.6 \%$ of the proportion of those employed; manufacturing employment constitutes $11.6 \%$; and the financial sector employs 3.9\% (see 2011 budget review). The 2010/11 - 2012/13 Industrial Policy Action Plan (IPAP 2) and the New Growth Path (NGP) that set out government's broad approach to industrialization, and which create a labor-absorbing path for the economy, further confirm the growing importance of the industrial sector. However, monetary authorities occupy a central position in stimulating industrial growth through output and price stability. Given that the industrial sector is essential, and because it is promoted by monetary policy, the need for an empirical investigation of this sector, which forms the basis of this study, cannot be overemphasized.

After an extensive review of the literature, there is, to the best of our knowledge, no study that has examined the impact of monetary policy shocks on industrial output growth and prices in South Africa. Similar papers by Kasai and Gupta (2010) and Gupta et al. (2010) have focused on the effects of monetary policy on real housing growth and prices in South Africa, while Rafiq and Mallick's (2008) study is on the effects of monetary policy shocks on output in the euro-area economy. Following this introduction, the rest of the paper is structured in five sections. Section 2 is a brief outline of South Africa's industrial sector performance and monetary policy; Section 3 deals with the financial crisis and industrial output in South Africa; Section 4presents the research methodology; estimation results follow in Section 5; and Section 6 summarises and concludes the paper.

\section{Monetary Policy Shocks and Industrial Sector Performance}

Do monetary policy shocks affect output growth? Kim (1999) argues that monetary policy shocks have significant effects on output in the short run. He further contends that a proportion of output fluctuations in the post war G-7 are attributed to monetary policy shocks. This view is also in line with Nagel and Parker (2003), who maintain that innovations (shocks) in any of the monetary policy variables have the potential to stimulate the economy. Chuku (2009) highlights the effects of monetary policy shocks on output and prices in the Nigerian economy, asserting that monetary policy shocks have both real and nominal effects on economic variables. He concludes that a change in money supply (M2) affects economic activity, and that monetary policy shocks have been a modest driver of the business cycle in Nigeria. Monetary policy shocks are also believed to explain borrowing and lending in the economy (see Christiano et al., 1999). However, it is common in economics to describe and summarise the effects of economic policy as having uniform outcomes across the economy as shown in the work of Carlino and Defina (1998). Ghosh (2009) however, observes that industries display varying degrees of responses to monetary policy shocks. This implies that the response of different sectors to economic policy or shocks varies, depending on their strength and capacity. For example, during the global recession, the action taken by monetary authorities to stimulate economies had asymmetric effects in different sectors. Among other studies, Peersman and Smets (2005) demonstrate an asymmetric response to monetary policy shocks in the eurozone. Akpan (2009) maintains that the asymmetric effects of global oil price shocks (positive or negative) have a significant impact on the rate of inflation in the economy.

However, many analysts believe that monetary policy in itself is a source of business cycles in the economy, and that the monetary authorities should weigh the options of output growth and price stability appropriately. Corsetti and Pesenti (2005) suggest an optimal monetary policy rule with a larger domestic output gap against lower consumer prices to stimulate growth, while Devereux et al. (2006) compare the alternative monetary policies for an emerging market economy and conclude that the best monetary policy 
rule is price stability. Nonetheless, as indicated by Bernanke et al. (2005), monetary authorities are tasked with the duty of analysing thousands of variables in their decision-making process to determine how to respond to a shock in the economy. Their decisions are usually well guided on price stability and output growth. Sousa and Zaghini (2007) reveal that the price level rises permanently in response to a positive shock to global liquidity and the impact of an unexpected change in Gross Domestic Product (GDP) and inflation. The monetary policy shocks can be either positive or negative depending on what the monetary authorities are aiming to achieve. Various approaches have been employed in the past to identify and estimate the impact of monetary policy shocks to the economy. Some examples include the ordinary vector autoregressive (VAR) approach, the Structural VAR (SVAR) approach, and the Factor Augmented Vector Autoregressive (FAVAR) Approach, among others. This study employs an SVAR with short run restrictions modelled on the South African economy to determine the impact of monetary policy shocks on industrial sector performance in the country. This is similar to Vonnák (2005), Berkelmans (2005), Cheng (2006), Chuku (2009) and Ngalawa and Viegi (2011) among others.

Financial Crisis and Industrial Output in South Africa: Many industries have recently been facing serious challenges brought about by a number of factors in both the international and domestic markets. However, the challenges faced by the industrial sector and the low production of aggregate output in South Africa can also be traced to the effects of the global financial crisis that started from the United State (US) and spread to other parts of the world (Vongi, 2010). The global financial crisis is believed to have caused a deterioration of South African financial conditions; an increase in unemployment, a slowdown in growth rate, and a decline in the growth of industrial output (see Baxter, 2009). Though it weathered the global storm relatively well, South Africa (ranked among the top 20 economies in the world, according to Baxter (2009), also suffered losses in which equity investors and depositors panicked, resulting in liquidity problems that adversely affected the ability of banks to offer loans to the industrial sector. According to Zini (2008), agriculture, mining and manufacturing declined while the trade and current account deficit (CAD) broadened. The falling global demand hurt South Africa's export sector and the country's GDP growth rate dropped to $1.8 \%$ in the last quarter of 2008 , before plunging to $-6.4 \%$ in the first quarter of 2009 , and to $-3.2 \%$ in the second quarter of 2009 (Padayachee, 2010).

Figure 1 shows industrial (manufacturing) sector employment during the period that immediately followed the global financial crisis. The low rates of growth in the manufacturing sector have resulted in consistent declines in manufacturing sector employment. Prior to 1990, industrial/manufacturing sector employment exhibited a slow but consistent rise. Since 1995, manufacturing employment has been on a persistent downward trend that has not reversed (Kaplan, 2004). With the very rapid rate of manufacturing growth between 2001 and 2002, manufacturing employment rose marginally. However, employment again fell significantly in 2003. This downward trend persisted during the global recession (2008 - 2010) but there was a turnaround in the fourth quarter of 2011. In the first quarter of 2013, the unemployment rate was estimated at 25.2 percent, according to Statistics South Africa's 2013 Labor Force Survey. In the second quarter of 2013, unemployment in South Africa rose to 25.60 percent, before decreasing again to 24.70 percent in the following quarter. 
Figure1: Manufacturing employment, Q3 2009 to Q4 2012

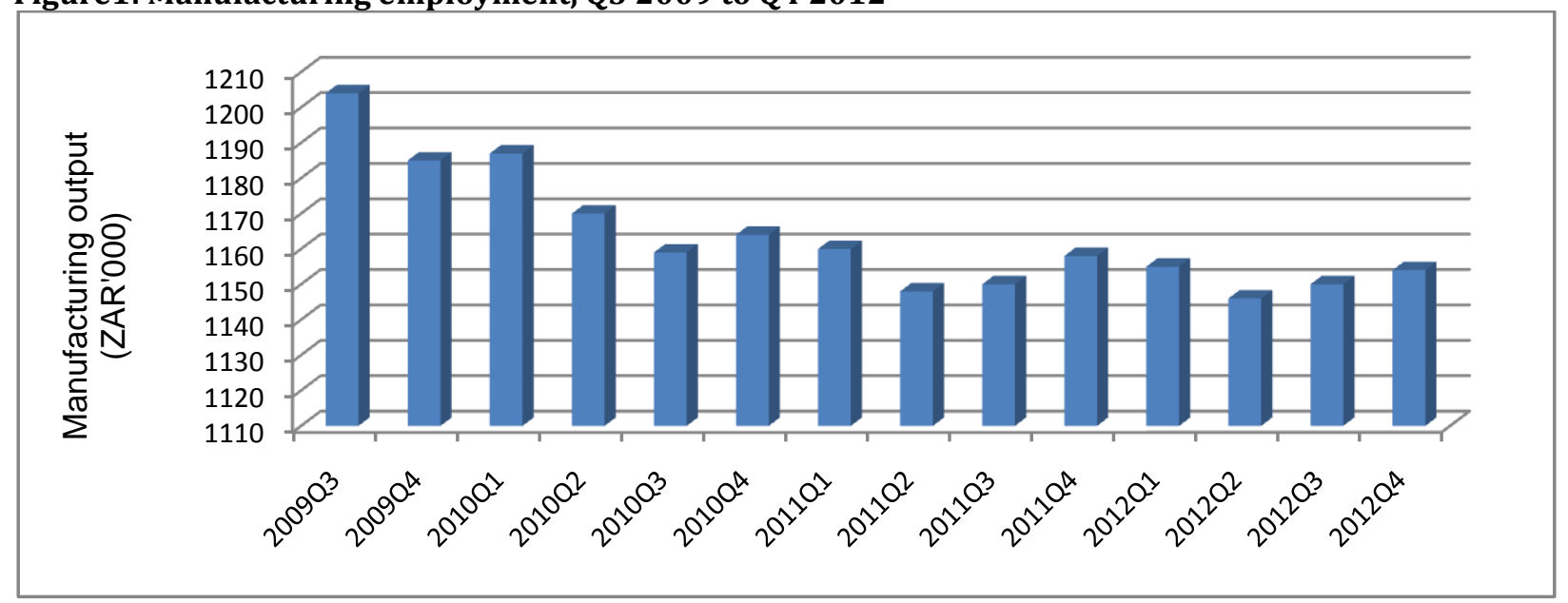

Source: author's computation from Stats South Africa data

\section{Data, Data Sources and Methodology}

Sources of data: The study uses monthly time series data spanning a period of 19 years from 1994:1 to 2012:12. The study period is post-apartheid South Africa and the cut-off dates have been dictated by data availability. The data are obtained from the South African Reserve Bank's statistical bulletins, Statistics South Africa, International Monetary Fund (IMF) and World Bank databases, Quantec Easydata Database and the Department of Trade and Industry (DTI) in South Africa. The choice of the domestic variables (with the exception of money supply) is in line with the existing study by Ibrahim and Amin (2005), while the two variables incorporated in the external sector are consistent with Cheng's (2006) study. Nominal values are used for exchange rates, interest rates and money supply; and real values are used for industrial performance and aggregate output.

Research technique: A model is structural if it allows for the prediction of the consequences of policy interventions or changes that occur within the economy. In our case, the application of a structural VAR will enable us to predict the effects of unexpected interventional policy actions by the monetary authorities to stimulate industrial sector performance. This approach is employed because it has several advantages. Firstly, it accounts for endogenous relationships and can summarise empirical relationships without placing too many restrictions on the data being utilised (Berkelmans, 2005). Secondly, by imposing only a minimal set of restrictions, it allows for the retention of an almost pure statistical flavour (Bulligan, 2010). Thirdly, it uses economic theory to categorise the contemporaneous relationships existing among variables. In addition, it can isolate the response of each variable to structural shocks and policy innovations over time (Van Aarle et al., 2003). Furthermore, the SVAR is employed to capture the behaviour of data due to its flexibility and ability to accommodate various relationships in a macroeconomic framework (Raghavan and Silvapulle, 2008). Rather than differencing the data, the analyses of persistence and spill over (propagation) effects will be carried out using impulse response functions of the SVAR in levels for various reasons, which are well documented in the literature. Ramaswamy and Sloek (1998), for instance, argue that while the impulse response functions of the VECM or differenced SVARs tend to imply that the impact of shocks is permanent, the impulse response functions derived from level SVARs allow time and history to determine whether the impacts of shocks are permanent or not. In addition, the SVARs in levels have a low computation burden and are particularly appealing for the test hypotheses on the monetary transmission mechanism due to the exogeneity of the monetary policy shocks.

More so, this study employs the research technique of Gottschalk (2001) and Sousa and Zaghini (2007) in examining the impact of monetary policy shocks on industrial sector performance in South Africa. Nonrecursive restrictions on the structural parameters are imposed and the $\mathrm{AB}$ model of Amisano and Giannini 
(1997) is adopted to carry out this task. This approach is appropriate for short-run restrictions where the speed of adjustment to a monetary policy shock is expected to be high. Generalised impulse response functions are further applied to perform the task of measuring the persistent and spill over effects. The response of industrial output (performance) to monetary policy shocks is evaluated by giving more attention to the dynamics of its persistence and the pass-through effects on the economy. The non-recursiveness assumption, which indicates that monetary policy shocks are orthogonal to the information set of the monetary authorities, further justifies the use of the SVAR methodology for examining the dynamic response of variables to monetary policy shocks compared to the $V A R$ analysis of simultaneous equation models that is only suitable for policy simulations. However, SVAR models cannot perform the same tasks as dynamic simultaneous equation models, but have the further advantage of avoiding some of the difficulties that characterise the traditional approach, and are well suited for structural analyses making investigation simple and straightforward.

Model specification and the set-up of the SVAR: The SVAR is estimated using six domestic variables, namely, industrial performance $(I P)$, aggregate output $(A G)$, exchange rate $(E X)$, inflation rate $(I F)$, interest rate $(I N)$ and money supply $(M S)$; and two external variables, namely, foreign commodity prices (comm) and global oil prices (oilprice). The two external variables are included to capture the open economy characteristics of the model. Industrial output (IP) is the industrial sector's contribution to GDP. Its analysis is at micro level proxied by manufacturing sector contribution to GDP while aggregate output (AG) is the real GDP minus industrial output. The subtraction is to enable the study to determine the impact of monetary policy shocks on industrial output and on GDP from other sectors separately. Assume the South African economy can be described according to the following structural equation:

$$
F Y_{t}=C_{o}+B_{1} Y_{t-1}+B_{2} Y_{t-2}+\cdots \ldots . .+B_{p} Y_{t-p}+\pi_{i} X_{t}+Z \varepsilon_{t}
$$

where $F$ is an invertible $(k \times k)$ matrix describing the contemporaneous relationship among the variables; $Y_{t}$ is a $(k \times 1)$ vector of endogenous variables such that $\left(Y_{t}=Y_{1 t}, Y_{2 t}, \ldots \ldots Y_{n t}\right) ; C_{o}$ is a $(k \times 1)$ vector of constants; $B_{i}$ is a $(k \times k)$ matrix of coefficients of lagged endogenous variables $($ for every $i=1 \ldots \ldots \ldots \ldots)$; $\pi_{i}$ and $X_{t}$ are the coefficients and vectors of the exogenous variables, respectively, capturing external shocks; $Z$ is a $(k \times k)$ matrix whose non-zero off-diagonal elements allow for direct effects of some shocks on more than one endogenous variable in the system; and $\varepsilon_{t}$ is an uncorrelated vector of error terms (white-noise structural disturbances).

The SVAR presented in equation (1) cannot be estimated directly due to the contemporaneous feedback inherent in the VAR process (Enders, 2004). The structure of the system incorporates feedback because the endogenous variables are allowed to affect each other in the current and past realisation time path of $F Y_{t}$. Therefore, the parameters are said to be unidentified and it is not possible to uniquely determine their values because the coefficients are unknown (McCoy, 1997). However, the information in the system can be recovered by estimating a reduced form VAR implicit in the equations (Ngalawa and Viegi, 2011). Premultiplying equation (1) by an inverse of matrix $F$ gives:

$$
Y_{t}=F^{-1} c_{o}+F^{-1} B_{1} Y_{t-1}+F^{-1} B_{2} Y_{t-2}+\ldots+F^{-1} B_{p} Y_{t-p}+F^{-1} \pi_{i} X_{t}+F^{-1} Z \varepsilon_{t}
$$

One can denote $F^{-1} C_{o}=C, F^{-1} B_{i}=A_{i}$ for $i=1 \ldots p, F^{-1} \pi_{i}=\alpha i$ and $F^{-1} Z \varepsilon_{t}=\mu_{t}$. Hence, equation becomes:

$$
Y_{t}=C+A_{1} Y_{t-1}+A_{2} Y_{t-2}+\ldots+A_{p} Y_{t-p}+\alpha_{i} X_{t}+\mu_{t}
$$

The difference between equations (1) and (3) is that, the first is called a structural VAR or primitive system where all variables have contemporaneous effects on each other, while the second is called a reduced form $V A R$ or a $V A R$ in standard form in which all the right-hand side variables are predetermined at time $t$ and no variable has a direct contemporaneous (immediate) effect on another in the model. In addition, the error term $\left(\mu_{t}\right)$ is a composite of shocks in $Y_{t}$ (Enders, 2004). Equation (3) can be rewritten in short form as:

$$
Y_{t}=B(L) Y_{t}+C(L) X_{t}+\mu_{t}
$$

Where:

$$
Y_{t}=\left[\begin{array}{llllll}
I P, & A G, \quad E X, \quad I F, \quad I N, \quad M S
\end{array}\right]
$$




$$
X_{t}=[\text { Comm, Oilprice }]
$$

Equation (4.1) is a vector of the South African endogenous variables used in the study; and equation (4.2) represents a vector of exogenous variables that control for external shocks and changes in world demand. $B(L)$ Is a matrix polynomial lag that captures the relationship between the endogenous variables? $\mu_{t}=B_{o}{ }^{-1} Z \varepsilon_{t}$ is a vector of random disturbances?

Suppose the structural shocks in equation (1) are identified according to the following scheme:

$$
\left[\begin{array}{c}
\varepsilon_{t}^{\log O P} \\
\varepsilon_{t}^{\log C O M} \\
\varepsilon_{t}^{I P} \\
\varepsilon_{t}^{\log A G} \\
\varepsilon_{t}^{I F} \\
\varepsilon_{t}^{\log M S} \\
\varepsilon_{t}^{\log E X} \\
\varepsilon_{t}^{\log I N}
\end{array}\right]=\left[\begin{array}{cccccccc}
1 & 0 & 0 & 0 & 0 & 0 & 0 & 0 \\
f_{21} & 1 & 0 & 0 & 0 & 0 & 0 & 0 \\
f_{31} & 0 & 1 & 0 & 0 & 0 & 0 & f_{38} \\
f_{41} & 0 & f_{43} & 1 & 0 & 0 & 0 & 0 \\
0 & 0 & f_{53} & f_{54} & 1 & f_{56} & 0 & 0 \\
f_{61} & f_{62} & 0 & 0 & f_{65} & 1 & f_{67} & 0 \\
f_{71} & f_{72} & f_{73} & f_{74} & f_{75} & f_{76} & 1 & 0 \\
0 & 0 & 0 & 0 & f_{85} & f_{86} & 0 & 1
\end{array}\right]\left[\begin{array}{c}
\mu_{t}^{\log O P} \\
\mu_{t}^{\log C O M} \\
\mu_{t}^{I P} \\
\mu_{t}^{\log A G} \\
\mu_{t}^{I F} \\
\mu_{t}^{\log M S} \\
\mu_{t}^{\log E X} \\
\mu_{t}^{\log I N}
\end{array}\right]
$$

The first two rows measure the external pressures on the domestic economy from oil price effects and commodity prices. Berkelmans (2005) argues that the transmission of international shocks to the domestic economy can be very rapid and that shocks are transmitted from the global market to the domestic market (and not the other way round). For instance, in the first and second equations, the oil price is assumed to be driving its own changes while the commodity prices depend on oil prices and their own fluctuations. The third and fourth equations are $V A R$ residuals that describe non-policy variables, while $I F, M S, E X$ and $I N$ are policy variables under the control of the monetary authorities; and $\mu_{t}$ is a vector of reduced form disturbances to both the foreign and domestic variables. The way variables influence each other depends on their position in the identification scheme. The non-zero coefficients $\left(f_{i j}\right)$ in the matrices indicate that variable $j$ affects variable $i$ instantaneously. For example, the first and second equations represent global oil prices and commodity prices, respectively. The oil prices $(O P)$ respond to their own lagged values while $f_{21}$ indicates that commodity prices $(C O M)$ respond contemporaneously only to $O P$. It further shows the sluggish reactions of $O P$ and $C O M$ to monetary policy shocks due to information and planning delays or lags faced by policy-makers (Sims \& Zha, 2006; Karame \& Olmedo, 2002; Bernanke \& Mihov, 1997; Berkelmans, 2005; Vonnák, 2005; Cheng, 2006). The third and fourth equations characterize the domestic goods market and the large number of zero restrictions in these rows is consistent with a model exhibiting nominal rigidities (Elbourne, 2008; Elbourne \&de Haan, 2006).

Coefficients $f_{31}$ and $f_{38}$ indicate that industrial production responds contemporaneously to $O P$ and $I N$, respectively, while $f_{41}$ and $f_{43}$ show a contemporaneous relationship between aggregate outputs on the one hand and $O P$ and $I P$ on the other. Rows 5 and 6 of the matrix represent the inflation rate and money supply. Coefficients $f_{53}, f_{54}$ and $f_{56}$ allow for contemporaneous relationships among industrial output, aggregate output and money supply on the one hand, and the rate of inflation on the other. The assumption of the contemporaneous response of inflation to output shocks is consistent with Brischetto and Voss (1999),Dungey and Pagan (2000), and Bernanke and Blinder (1992). Money supply (row 6) responds instantaneously only to $O P, C O M, I F$ and $E X$. The basic idea underlying the SVAR approach for $M S$ is that not all changes in the monetary policy stance reflect a systematic response to variations in the state of the economy (Sousa and Zaghini, 2007). This is the reason for the sluggish response to $I P, A G$ and $I N$. Row 7 shows that the exchange rate $(E X)$ is set in a competitive market and thus responds contemporaneously to all the variables in the system, while the interest rate $(I N)$ as a policy variable only responds to $I F$ and $M S$ as shown by $f_{85}$ and $f_{86}$, respectively. 


\section{Empirical Results and Data Analysis}

The lag length: The study tests for various lag lengths using different selection criteria in order to allow for adjustments in the model and the attainment of well-behaved residuals. The standard Akaike Information Criteria (AIC) and Hannan-Quinn Criteria (HQC) suggest 2-lags while the Final Prediction Error (FPE), Sequential Modified LR test and Schwarz Information Criterion (SIC) suggest 8-lags as the optimal lag length. Consistent with previous studies, this study adopts the optimal lag length suggested by the AIC (see, for example Suzuki, 2004; Ngalawa and Viegi, 2011).

Impulse response functions: Impulse responses are constructed for shocks to all variables in the SVAR model to provide an exogenous source of variation that allows us to identify the response of selected variables in the economy to monetary policy shocks. Figures 1-8show the impulse responses of a structural one-standard-deviation shock on selected variables.

The impulse response of industrial sector performance (IP): Figure 2shows that shocks to exchange rates, interest rates and commodity prices have no significant impact on industrial sector performance. However, an aggregate output shock significantly increases industrial output growth beginning from about three months after the shock and peaking at about seven months before gradually returning to equilibrium. This reveals that an aggregate output shock has a positive and significant impact on industrial output growth. The positive aggregate output shock may indicate an increase in the production of goods and services that is likely to have important forward and backward linkages to industrial production, which probably explains the positive response of industrial output growth.

Furthermore, it is observed that a price shock leads to a near-instantaneous significant positive increase in industrial output growth, which peaks at about three months (see Figure 2). Assuming imperfect information, if producers of industrial output observe an increase in the prices of their products, they may not know whether the general price level has gone up or the relative prices have changed. In the case of perfect information, the industrial output producers would be expected to do nothing if they are able to identify the price increase of their products as being a result of a general price increase. However, if they identify it as a relative price change, they are expected to respond by adjusting their output. In the more realistic case of imperfect information, an optimal response would be to presume that with some probability the general price level has increased and with some probability, relative prices have changed. The producers would, therefore, increase output, but not to the full extent that absorbs the price increase. This probably explains the increase in industrial production following a price increase. We further observe that a money supply shock has a significant positive impact on industrial output growth from about the eighth months. This may trigger a price increase, which in turn increases industrial output.

Figure 2: Responses of IP to Shocks AG, EX, IF, IN, MS, COMM and OP

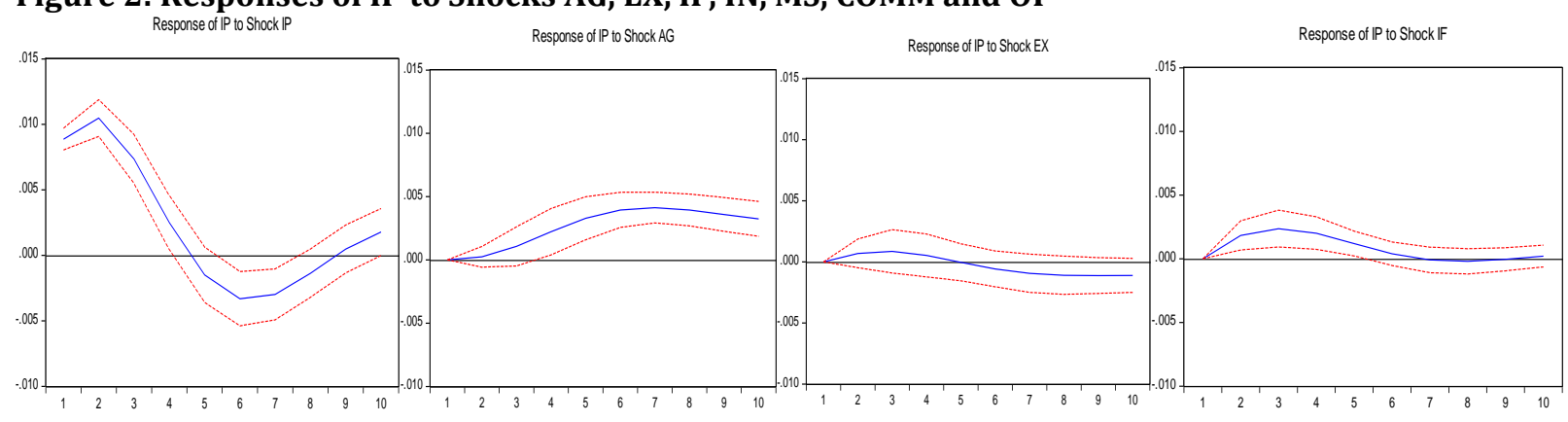




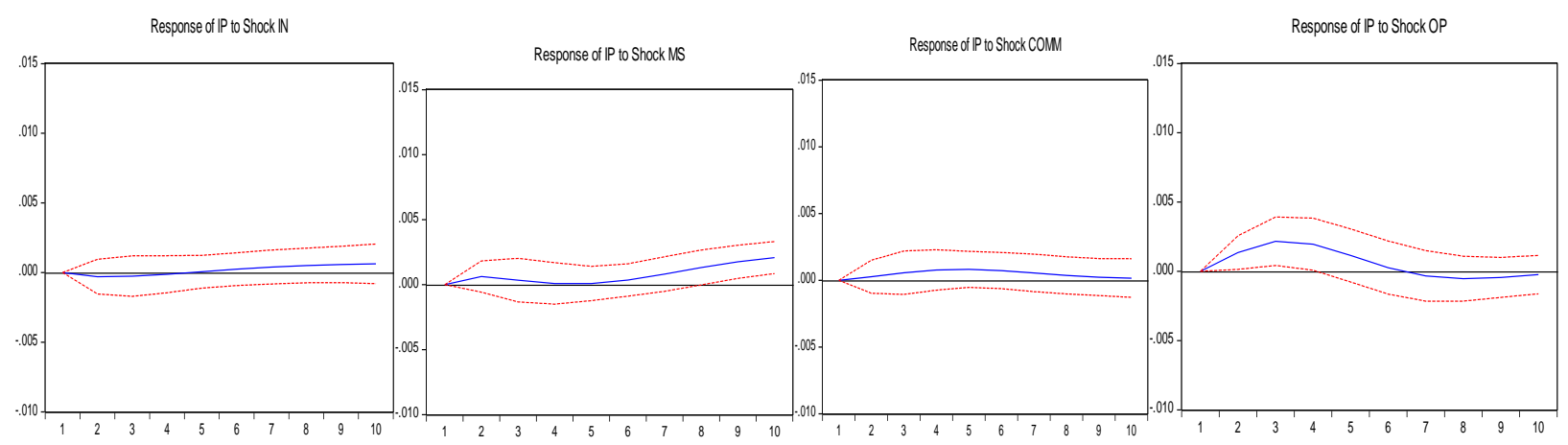

The impulse response of aggregate output (AG): Figure 3reveals that following an industrial performance shock, aggregate output responds with an instantaneous decline, which bottoms out after two months and starts rising until about the seventh month when it reaches a peak. Thereafter, it slowly returns to equilibrium. This shows that industrial output eventually increases aggregate output significantly although the initial impact is negative. It is also observed that a money supply shock causes aggregate output to increase significantly from about the fifth month. However, the shocks to exchange rates, inflation rates (prices), interest rates and commodity prices result in insignificant responses in industrial output growth.

Figure3: Responses of AG to Shocks IP, EX, IF, IN, MS, COMM and OP
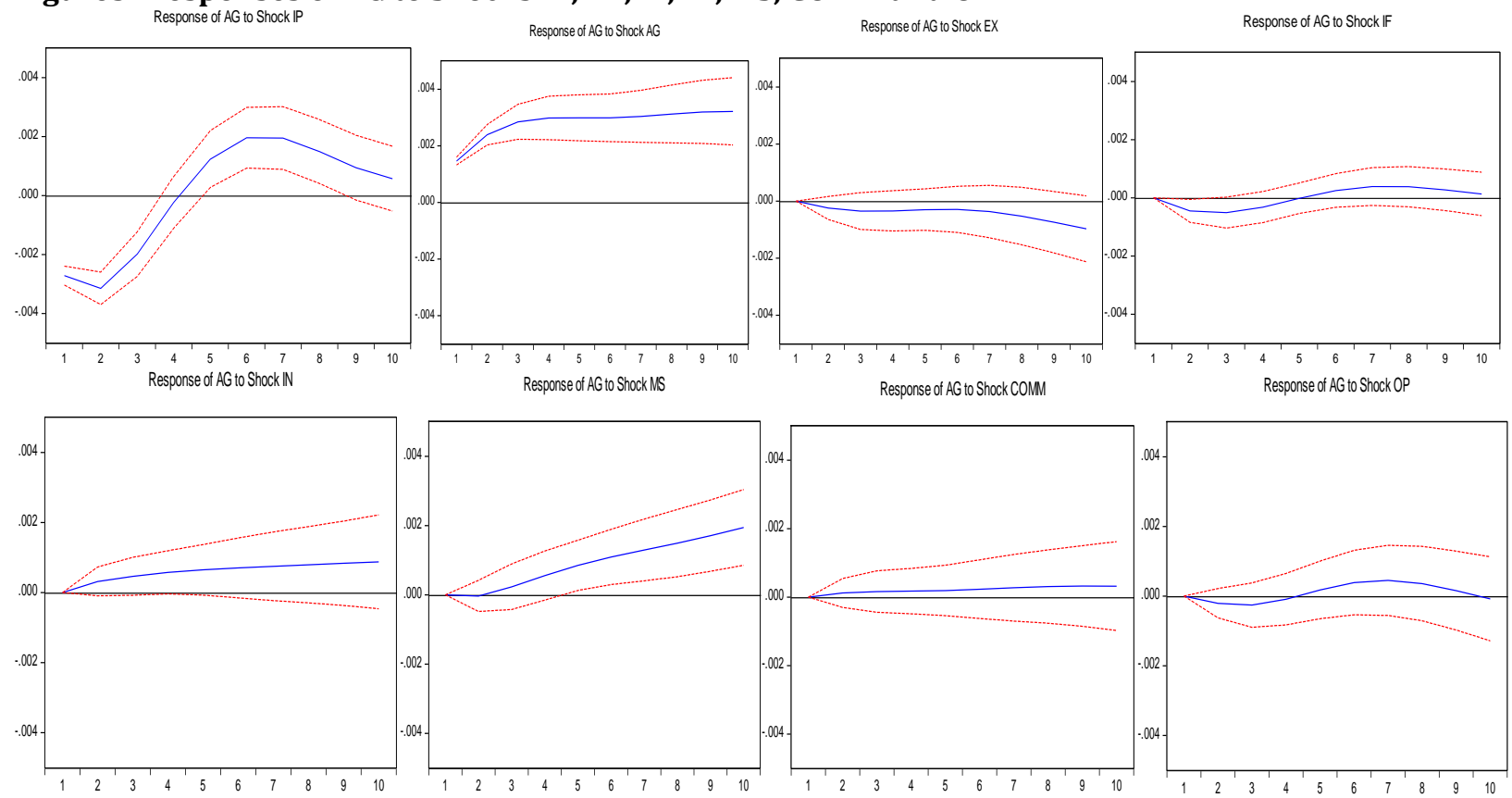

The impulse response of exchange rate (EX): Figure4 shows that industrial output growth, aggregate output, prices, interest rates and money supply shocks have an insignificant impact on the exchange rate of the South African rand against the United States dollar. This might not be unconnected to the floating exchange rate system in South Africa as the market value of the currency is determined by the forces of supply and demand. However, a global oil price shock leads to a significant instantaneous appreciation of the rand against the United States dollar, which bottoms out after about three months. Thereafter, the rand starts to depreciate against the United States dollar as it returns to equilibrium. This finding, that an oil price shock can result in an appreciation of the rand vis-à-vis the US dollar in the short run, is inconsistent with Riman et al. (2013). 
Figure 4: Responses of EX to Shocks IP, AG, IF, IN, MS, COMM and OP
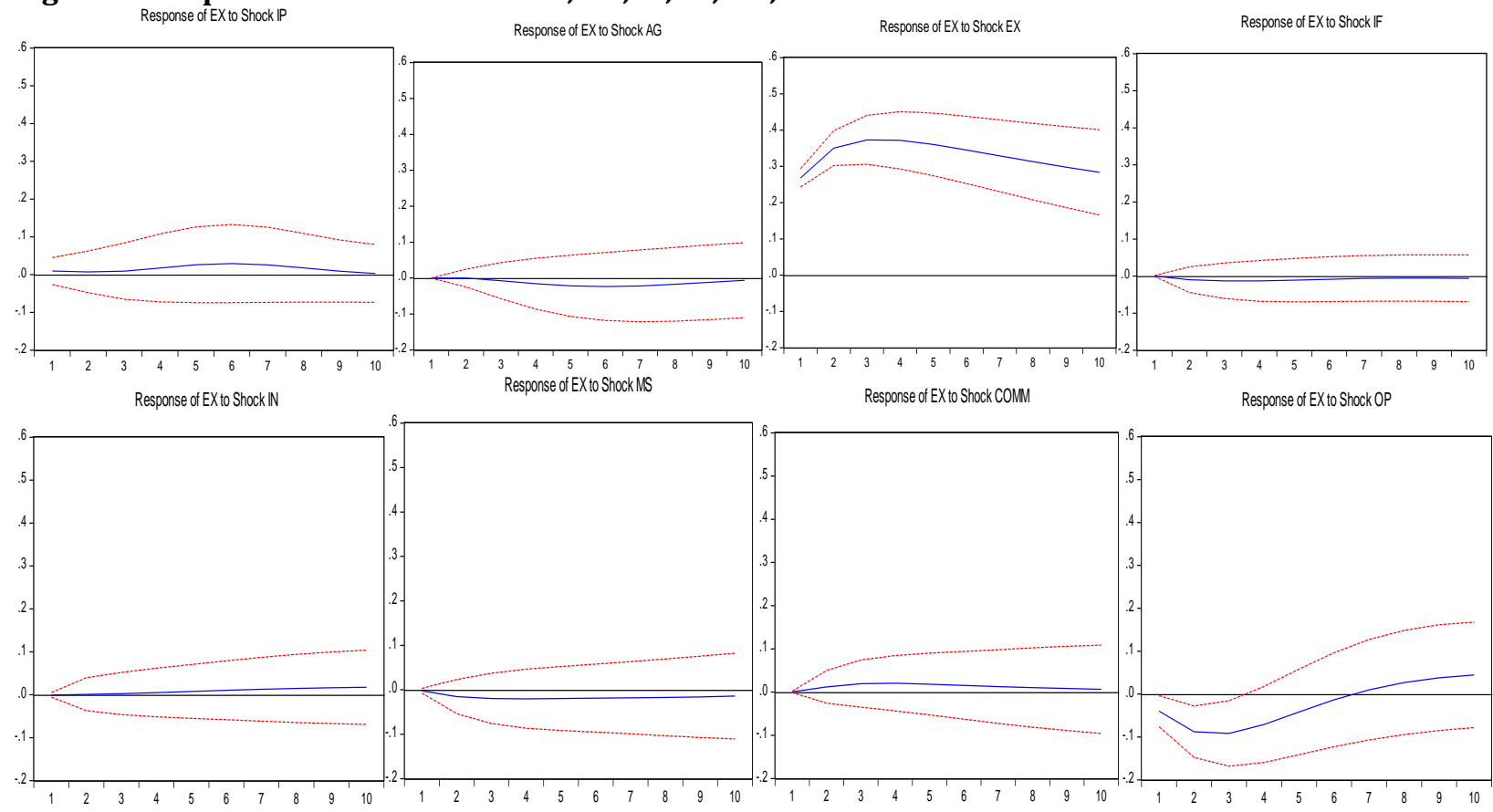

The impulse response of inflation rate (IF): Impulse response functions of inflation rates following selected shocks are presented in Figure 5. The figure shows that inflation rates respond insignificantly to aggregate output, interest rates and commodity price shocks. A positive industrial production shock causes inflation to drop instantaneously, bottoming out after about five months before rising again towards equilibrium. This is probably due to excess supply of goods and services putting downward pressure on prices. Firms are likely to respond to this occurrence by cutting back on production, forcing prices to start adjusting back to equilibrium after five months. As expected, a positive oil price shock characterised by a sudden increase in oil prices and an exchange rate shock (an unanticipated depreciation of the rand against the United States dollar) results in significant increases in the rates of inflation.

Figure 5: Responses of IF to Shocks IP, AG, EX, IN, MS, COMM and OP

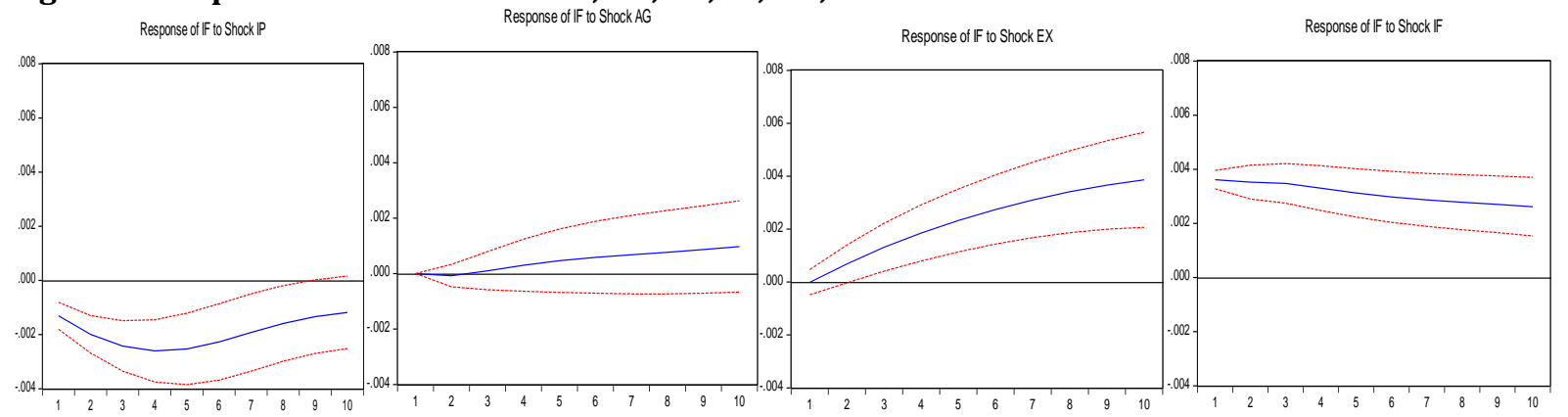




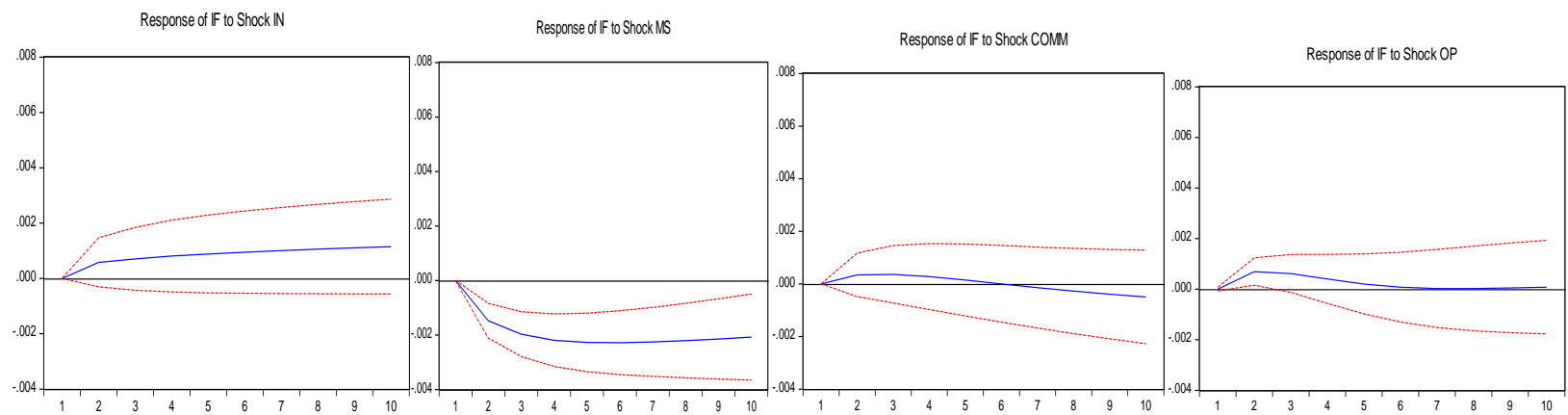

The impulse response of interest rate (IN): Industrial output, real GDP, inflation rates, commodity prices and global oil price shocks have an insignificant impact on interest rates in the economy (see Figure 6).However, an exchange rate shock causes interest rates to increase significantly from about the second period, peaking after about six periods. This is consistent with our prior theoretical expectations. As the South African rand depreciates against the US dollar, domestic goods become relatively cheaper, which leads to an increase in the demand for rands, consequently putting upward pressure on domestic interest rates. It is also observed that a money supply shock causes an instantaneous decline in interest rates, bottoming out after about three months. Again, this is consistent with the theory.

Figure 6: Responses of IN to Shocks IP, AG, EX, IF, MS, COMM and OP

Response of IN to Shock IP

Response of IN to Shock AG

Response of N to ShockEX

Response of IN to Shock IF

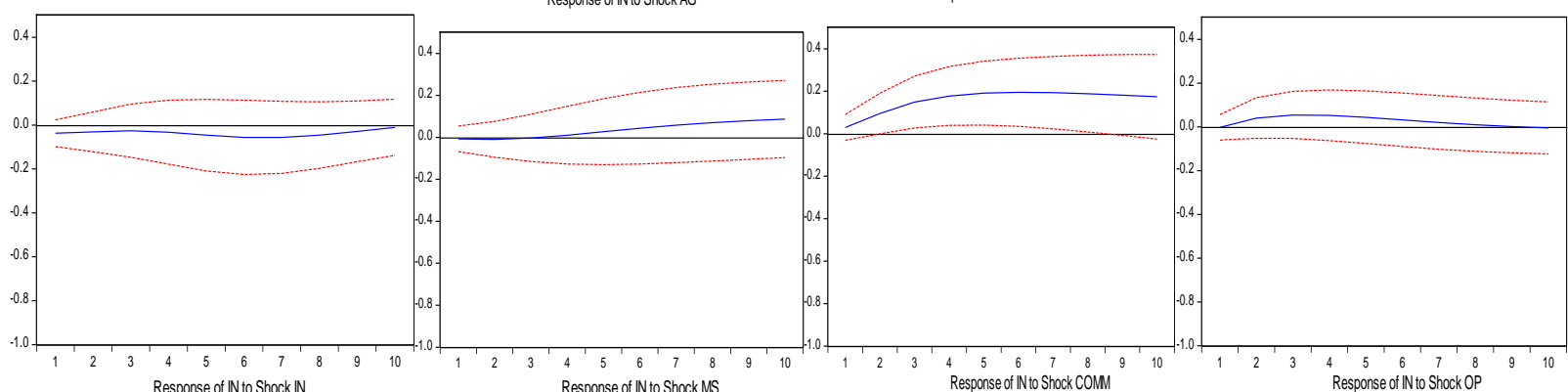

Response of IN to Shock IN

Response of IN to Shock MS

Response of IN to Shock COMM
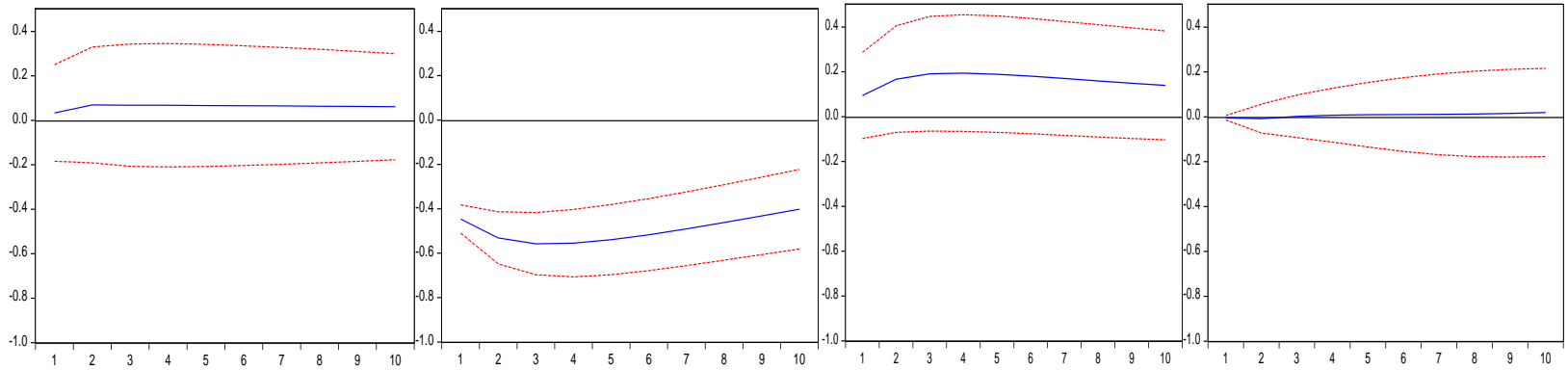

Variance decomposition: According to Raghavan and Silvapulle (2008), variance decomposition describes what percentage of a shock linked to a specific variable is related to either its own innovations or those associated with other dependent variables, at various forecasted time limits in a model. It analyses the relative importance of shocks in explaining variations among variables. In the context of this study, the variance decomposition helps to determine the relative importance of various shocks to all the variables in the model. We analyse a 12-month period, which is subdivided into 4 quarters (3, 6, 9 and 12 months) for convenient and easy interpretation of the results. 
Table 1: Variance decomposition of industrial performance (IP)

\begin{tabular}{|c|c|c|c|c|c|c|c|c|}
\hline & $\begin{array}{l}\text { iodStandard Industrial } \\
\text { Error performanc }\end{array}$ & $\begin{array}{l}\text { Aggregate } \\
\text { ceoutput }\end{array}$ & $\begin{array}{l}\text { Exchange } \\
\text { rate }\end{array}$ & $\begin{array}{l}\text { Inflation } \\
\text { rate }\end{array}$ & $\begin{array}{l}\text { Interest } \\
\text { rate }\end{array}$ & $\begin{array}{l}\text { Money } \\
\text { supply }\end{array}$ & $\begin{array}{l}\text { Foreign } \\
\text { prices }\end{array}$ & $\begin{array}{l}\text { Global oil } \\
\text { prices }\end{array}$ \\
\hline 3 & & & & & & 77 & 33 & 49 \\
\hline 6 & & & & & & 503 & 08 & 451 \\
\hline 9 & & & & & & 938 & 951 & 143 \\
\hline 12 & 0.02131962 .75630 & 23.23905 & 2.040187 & 3.316175 & 0.495122 & 4.819203 & 0.608923 & 2.725039 \\
\hline
\end{tabular}

Variance decomposition of industrial sector performance (IP): Table1 presents the variance decomposition of industrial sector performance. The table reveals that $92.75 \%$ of the fluctuations in industrial output growth in the first period are explained by industrial output growth itself. Inflation rate accounts for $3.43 \%$ while oil prices account for $2.50 \%$ of the variations in industrial sector performance. Each of the remaining variables accounts for less than $1 \%$ of the industrial sector performance variations. However, after six months, aggregate output accounts for the largest proportion of the variations in industrial sector performance (apart from its own impact), estimated at $19.85 \%$, which increases to $23.24 \%$ after a year. The contribution of oil prices to industrial sector performance is still recorded at below $3 \%$ after a year. The proportion of variations in industrial output attributed to money supply, however, increases from under $1 \%$ in the first month to nearly $5 \%$ after a year. The contribution of interest rates to variations in industrial production remains below $1 \%$ in all periods up to one year. This may indicate that industrial producers in South Africa are not constrained by the cost of credit in their production of goods and services.

Variance decomposition of aggregate output (AG): Table 2 shows that industrial output growth accounts for the largest proportion of the variations in aggregate output, besides aggregate output itself. The variations in aggregate output attributed to industrial output, however, decline over time. The table shows that industrial output explains 55.31\%, 35.62\%, 27.60\% and $19.80 \%$ of the fluctuations in aggregate output after $3,6,9$ and 12 months, respectively. The contribution of exchange rates, interest rates and money supply to variations in aggregate output are observed to increase in the second, third and fourth quarters.

Table 2: Variance decomposition of aggregate output

\begin{tabular}{|c|c|c|c|c|c|c|c|c|}
\hline & $\begin{array}{l}\text { AStandard Industrial } \\
\text { error performane }\end{array}$ & Aggregate & $\begin{array}{l}\text { Exchange } \\
\text { rate }\end{array}$ & $\begin{array}{l}\text { Inflation } \\
\text { rate }\end{array}$ & $\begin{array}{l}\text { Interest } \\
\text { rate }\end{array}$ & $\begin{array}{l}\text { Money } \\
\text { supply }\end{array}$ & $\begin{array}{l}\begin{array}{l}\text { Foreign } \\
\text { prices }\end{array} \\
\end{array}$ & $\begin{array}{l}\text { Global oil } \\
\text { prices }\end{array}$ \\
\hline 3 & & & & & & & & \\
\hline 6 & & & & & & & & \\
\hline 9 & & & & & & & & \\
\hline 12 & 0.01320619 .79598 & 58.35179 & 3.279454 & 0.586282 & 3.401386 & 613.63636 & 0.413820 & 0.534933 \\
\hline
\end{tabular}

Variance decomposition of the exchange rate (EX): Table 3 reveals that variations in exchange rates are largely explained by exchange rates themselves, corroborating the Martingale Hypothesis of exchange rates. An estimated $94.50 \%, 95.93 \%, 96.36 \%$ and $96.35 \%$ of the fluctuations in exchange rates are explained by exchange rates themselves after 3, 6, 9 and 12 months, in that order. Besides the exchange rates themselves, it is observed that oil prices account for $5.02 \%, 3.28 \%, 2.56 \%$ and $2.63 \%$ of the exchange rate variations after 3 , 6, 9 and 12 months, respectively.

Table 3: Variance decomposition of exchange rates

\begin{tabular}{|c|c|c|c|c|c|c|c|c|}
\hline$\overline{\text { Per }}$ & $\begin{array}{l}\text { iodStandard Industrial } \\
\text { error performan }\end{array}$ & $\begin{array}{l}\text { Aggregate } \\
\text { ooutput }\end{array}$ & $\begin{array}{l}\text { exchange } \\
\text { rate }\end{array}$ & $\begin{array}{l}\text { Inflation } \\
\text { rate }\end{array}$ & $\begin{array}{l}\text { Interest } \\
\text { rate }\end{array}$ & $\begin{array}{l}\text { Money } \\
\text { supply }\end{array}$ & $\begin{array}{l}\begin{array}{l}\text { Foreign } \\
\text { prices }\end{array} \\
\end{array}$ & $\begin{array}{l}\text { Global oil } \\
\text { prices }\end{array}$ \\
\hline 3 & 0 & 0 & & & & & & 14 \\
\hline 6 & 0.86 & 0.1 & 95 & 0.0 & 0.0 & 0.2 & 55 & 715 \\
\hline 9 & 1.0 & 0.2 & 96. & & 0.0 & 0.2 & 80 & 764 \\
\hline 12 & 1.1327830 .245039 & 0.178575 & 96.34634 & 0.066009 & 0.142670 & 0.24095 & 0.150246 & 2.630177 \\
\hline
\end{tabular}


Variance decomposition of inflation rates (IF): Table 4 presents the variance decomposition of inflation rates. Besides its own variations, exchange rates account for the largest share of inflation fluctuations. After 3 , 6, 9 and 12 months, exchange rates account for 3.69\%, 13.05\%, 23.35\% and 31.65\% of the variations in inflation rates, respectively. As predicted by the theory, money supply also accounts for a relatively large share of the inflation variations. It is estimated that $10.22 \%, 14.94 \%, 15.70 \%$ and $14.89 \%$ of the fluctuations in inflation rates are explained by changes in money supply after 3, 6, 9 and 12 months, in that order. Thus, depreciation of the South African rand against the US dollar and money supply growth are the main factors that explain variations in inflation rates in South Africa.

Table4: Variance Decomposition of inflation rates (IF)

\begin{tabular}{|c|c|c|c|c|c|c|c|c|}
\hline $\mathbf{P e}$ & $\begin{array}{l}\text { iodStandard Industrial } \\
\text { error performan }\end{array}$ & $\begin{array}{l}\text { Aggregate } \\
\text { eutput }\end{array}$ & $\begin{array}{l}\text { exchange } \\
\text { rate }\end{array}$ & $\begin{array}{l}\text { Inflation } \\
\text { rate }\end{array}$ & $\begin{array}{l}\text { Interest } \\
\text { rate }\end{array}$ & $\begin{array}{l}\text { Money } \\
\text { supply }\end{array}$ & $\begin{array}{l}\text { Foreign } \\
\text { prices }\end{array}$ & $\begin{array}{l}\text { Global oil } \\
\text { prices }\end{array}$ \\
\hline 3 & & & & & & & & \\
\hline 6 & & & & & & & & \\
\hline 9 & & & 23 & & & & & 438 \\
\hline 12 & 0.01787013 .00193 & 1.931307 & 31.65568 & 34.28140 & 3.374583 & 14.89041 & 10.518276 & 0.346402 \\
\hline
\end{tabular}

Variance decomposition of interest rate (IN): Table 5 presents the variance decomposition of interest rates. The table reveals that money supply accounts for the largest proportion of the variations in interest rates, estimated at $86.47 \%, 81.96 \%, 79.79 \%$ and $78.29 \%$ after 3, 6, 9 and 12 months, respectively. This is consistent with a priori theoretical expectations. The table also shows that exchange rates and international commodity prices account for nearly the same proportion of the fluctuations in interest rates. Exchange rates account for $3.06 \%, 5.24 \%, 5.67 \%$ and $5.20 \%$ of the variations in interest rates after 3, 6, 9 and 12 months, in that order, while oil prices account for $8.02 \%, 8.89 \%, 8.91 \%$ and $8.89 \%$ of the fluctuations in interest rates after 3, 6, 9 and 12 months, respectively.

Table 5: Variance Decomposition of Interest Rates

\begin{tabular}{|c|c|c|c|c|c|c|c|c|}
\hline Peri & $\begin{array}{c}\text { iodStandard Industrial } \\
\text { error performanc }\end{array}$ & $\begin{array}{l}\text { Aggregate } \\
\text { ceoutput }\end{array}$ & $\begin{array}{l}\text { exchange } \\
\text { rate }\end{array}$ & $\begin{array}{l}\text { Inflation } \\
\text { rate }\end{array}$ & $\begin{array}{l}\text { Interest } \\
\text { rate }\end{array}$ & $\begin{array}{l}\text { Money } \\
\text { supply }\end{array}$ & $\begin{array}{l}\begin{array}{l}\text { Foreign } \\
\text { prices }\end{array} \\
\end{array}$ & $\begin{array}{l}\text { Global oil } \\
\text { prices }\end{array}$ \\
\hline 3 & & & & & & & & \\
\hline 6 & & & & & & & & \\
\hline 9 & & & & & & & & \\
\hline 12 & 1.8619010 .460189 & 1.263361 & 9.370255 & 0.323125 & 1.342043 & 78.2909 & 38.885097 & 0.065003 \\
\hline
\end{tabular}

\section{Conclusion and Policy Implications}

This study set out to investigate the impact of monetary policy shocks on industrial sector performance (output) and how the shocks spread through the economy. Using a Structural Vector Auto regression (SVAR) model and monthly data from 1994:1 to 2012:12, the study finds no direct link between exchange rate and interest rate shocks and industrial output growth. A money supply shock, however, has a significant positive impact on industrial output growth from about the eighth month. The study by Aron and Muellbauer (2002) on monetary policy for the periods 1986 to 1997 is also consistent with this view. This study also observes that monetary authorities respond to an unanticipated increase in the rate of inflation by gradually increasing interest rates. The response, however, is insignificant. This may be a reflection of the infrequent changes of the REPO rate (relative to the monthly changes in the rate of inflation) and also linked to regime shifts and control of structural changes as indicated by Aron and Muellbauer (2002). The study also finds that following a positive industrial performance shock, aggregate output responds contemporaneously, initially declining for the first two months and later rising, peaking after about seven months. This shows that industrial output eventually increases aggregate output significantly although the initial impact is negative. The initial negative impact suggests that an unexpected growth in industrial output initially slows down the growth of other sectors in the economy, leading to a net decline in aggregate output. 
This study also examines the response of industrial output, aggregate output and other macroeconomic variables to global oil price shocks. It is discovered that a global oil price shock significantly affects industrial output, exchange rates and the general price level within a short period, but insignificantly affects aggregate (real) output, interest rates, money supply and commodity prices for the whole study period. However, there is a notable fluctuation (upward and downward trends) in all the variables, apart from interest rates, for the entire period. This further supports the views of Monfort et al. (2003), Mansour (2003), Lumsdaine and Prasad (2003) and Canova et al. (2007) that fluctuations of most macroeconomic variables across countries are mainly driven by a global factor. The existence of a world cycle provides evidence of the linkages that macroeconomic variables have across countries. In other words, this world linkage is significant proof of economic integration existing among various countries' economies. There is evidence of persistence and propagation effects in price (impulse response of inflation rates) and interest rates (impulse response of interest rates). The importance of a transmission channel following a monetary policy shock to commodity prices, which is linked to global oil prices, will depend on how the exchange rate plays its role in this linkage over time (see Harri et al., 2009).

Variance decomposition reveals that interest rates explain less than $1 \%$ of the variations in industrial output growth, even after a year. Money supply, on the other hand, accounts for only an estimated $5 \%$ of the variations in industrial production. Aggregate output, however, explains up to $23 \%$ of the variations in industrial output after a year. The policy implication of these findings is that the monetary authorities have very limited control over industrial output growth using instruments of monetary policy in South Africa. The only way they can influence industrial output growth is indirectly by influencing the growth of aggregate output. This underscores the importance of forward and backward linkages in the real sector for industrial sector growth. Confirming this finding, the study reveals that industrial output growth accounts for more than half of the variations in aggregate output within a quarter. The contribution of industrial output growth to variations in aggregate output declines (from 55\% after the first quarter to $36 \%, 28 \%$ and $20 \%$ after the second, third and fourth quarters, respectively) but remains considerably large.

The study also finds that relatively large proportions of the variations in the rate of inflation are explained by changes in money supply, exchange rates and industrial output. We further observe that variations in exchange rates are largely explained by unexpected changes in the exchange rates themselves, which supports the Martingale Hypothesis of exchange rates. This is also consistent with the fact that the South African rand has a freely floating exchange rate. Thus, the monetary authorities cannot effectively use the exchange rate to influence the general price level. The study also shows that interest rate variations are not explained by unanticipated changes in the rate of inflation, as the country's inflation targeting framework would suggest. Rather, about $86 \%$ of the variations in interest rates are explained by unexpected money supply changes in the first quarter. While the contribution of money supply in interest rate variations declines to $82 \%$ in the second quarter, $80 \%$ in the third quarter and $78 \%$ in the fourth quarter, it remains very high.

\section{References}

Amisano, G. \& Giannini, C. (1997). Topics in structural VAR econometrics (2nd Ed), Berlin: Springer.

Akpan, E. O. (2009). Oil price shocks and Nigeria's macro economy. A paper presented at the Annual Conference of CSAE Conference, Economic Development in Africa, 22-24 March, Oxford, United Kingdom.

Aron, J. \& Muellbauer, J. (2002). Interest rate effects on output: evidence from a GDP forecasting model for South Africa. An IMF Staff Paper No. 49.

Berkelmans, L. (2005). Credit and monetary policy: An Australian SVAR. Reserve Bank of Australia Discussion Paper 2005-06.

Baxter, R. (2009). The global economic crisis and its impact on South Africa and the country's mining industry. Challenges for Monetary Policy-makers in Emerging Markets, 105.

Bernanke, B. S. \& Blinder, A. S. (1992). The federal funds rate and the channels of monetary transmission. American Economic Review, 82(4), 901-921. 
Bernanke, B., Boivin, J. \& Eliasz, P. (2005). Measuring the effects of monetary policy: A factor-augmented vector autoregressive (FAVAR) approach. Quarterly Journal of Economics, 120(1), 387-422.

Bernanke, B. S. \& Mihov, I. (1997). What does the Bundes bank target? European Economic Review, 41, 10251053.

Brischetto, A. \& Voss, G. (1999). A structural vector autoregression model of monetary policy in Australia. Reserve Bank of Australia Research Discussion Paper 1999-11.

Bulligan, G. (2010). Housing and the macro economy: The Italian case. Housing Markets in Europe, 10, 19-38.

Canova, F., Ciccarelli, M. \& Ortega, E. (2007). Similarities and convergence in G-7 cycles. Journal of Monetary Economics, 54(3), 850-878.

Carlino, G. \& Defina, R. (1998). The differential regional effects of monetary policy. Review of Economics and Statistics, 80, 572-587.

Cheng, M. K. C. (2006). A VAR Analysis of Kenya's monetary policy transmission mechanism: How does the central bank's REPO rate affect the economy? IMF Working Paper WP/06/300.

Christiano, L. J., Eichenbaum, M. \& Evans, C. L. (1999). Monetary policy shocks: What have we learned and to what end? Handbook of Macroeconomics, 1, 65-148.

Chuku, C. A. (2009). Measuring the effects of monetary policy innovations in Nigeria: A structural vector autoregressive (SVAR) approach. African Journal of Accounting, Economics, Finance and Banking Research, 5, 1-18.

Corsetti, G. \& Pesenti, P. (2005). International dimensions of optimal monetary policy. Journal of Monetary Economics, 52, 281-305.

Devereux, M. B., Lane, P. R. \& Xu, J. (2006). Exchange rates and monetary policy in emerging market economies. The Economic Journal, 116, 478-506.

Dungey, M. \& Pagan, A. (2000). A structural VAR model of the Australian economy. Economic Record, 76, 321342.

Elbourne, A. (2008). The UK housing market and the monetary policy transmission mechanism: An SVAR approach. Journal of Housing Economics, 17, 65-87.

Elbourne, A. \& De Haan, J. (2006). Financial structure and monetary policy transmission in transition countries. Journal of Comparative Economics, 34, 1-23.

Enders, W. (2004). Applied Econometric Time Series (3rd Ed). New York: John Wiley \& Sons.

Ghosh, S. (2009). Industry effects of monetary policy: Evidence from India. (MPRA Paper No. 17307). Available http://mpra.ub.uni-muenchen.de/17307. [Accessed on 22 June 2015]

Gottschalk, J. (2001). An introduction into the SVAR methodology: Identification, interpretation and limitations of SVAR models. (Keil Working Paper No. 1072).

Gupta, R., Jurgilas, M. \& Kabundi, A. (2010). The effect of monetary policy on real house price growth in South Africa: A factor-augmented vector autoregression (FAVAR) approach. Economic Modeling, 27, 315323.

Harri, A., Nalley, L. \& Hudson, D. (2009). The relationship between oil, exchange rates, and commodity prices. Journal of Agricultural and Applied Economics, 41(2), 501-510.

Ibrahim, M. H. \& Amin, R. M. (2005). Exchange rate, monetary policy and manufacturing output in Malaysia. Journal of Economic Cooperation, 26, 103-130.

Kaplan 1, D. (2004). Manufacturing in South Africa over the last decade: A review of industrial performance and policy. Development Southern Africa, 21(4), 623-644.

Karame, F. \& Olmedo, A. (2002). The asymmetric effects of monetary policy shocks: A nonlinear structural VAR approach. European Science Foundation. Journal of Money, Credit and Banking, 31, 85-108.

Kasai, N. \& Gupta, R. (2010). Financial liberalization and the effectiveness of monetary policy on house prices in South Africa. IUP Journal of Monetary Economics, 8, 59-74.

Kim, S. (1999). Do monetary policy shocks matter in the G-7 countries? Using common identifying assumptions about monetary policy across countries. Journal of International Economics, 48, 387412.

Lumsdaine, R. L. \& Prasad, E. S. (2003). Identifying the Common Component of International Economic Fluctuations: A New Approach. The Economic Journal, 113(484), 101-127.

Mansour, J. M. (2003). Do national business cycles have an international origin? Empirical Economics, 28(2), 223-247. 
McCoy, D. (1997). How useful is Structural VAR Analysis for Irish economics? Economic Analysis, Research and Publication Department, Central Bank of Ireland. (Technical Working Paper 2/RT/97).

Mihov, I. (2001). Monetary policy implementation and transmission in the European Monetary Union. Economic Policy, 16(33), 369-403.

Monfort, A., Renne, J. P., Rüffer, R. \& Vitale, G. (2003). Is economic activity in the G7 synchronized? Common shocks versus spillover effects. CEPR Discussion Papers No. 4119.

Mountford, A. \& Uhlig, H. (2009). What are the effects of fiscal policy shocks? Journal of Applied Econometrics, 24, 960-992.

Nagel, A. \& Parker, J. (2003). Empirical macroeconomics: The effects of monetary policy. Gold-Hammer Collaborative Research at the Department of Economics, Reed College. http://academic.reed.edu/economics/course_pages/341_s09/Monetary_Policy_Chapter.pdf [Accessed on 19 March 2015]

Ngalawa, H. \& Viegi, N. (2011). Dynamic effects of monetary policy shocks in Malawi. South African Journal of Economics, 79, 224-250.

Padayachee, V. (2010). Global economic recession: effects and implications for South Africa at a time of political challenges. http://www.lse.ac.uk/internationalDevelopment/20thAnniversaryConference/ImpactoftheGlobalFC .pdf

Pedersen, M. (2011). Propagation of shocks to food and energy prices: an international comparison. Available http://www.bcentral.cl/estudios/documentos-trabajo/pdf/dtbc648.pdf. [Accessed on 22 June 2015]

Peersman, G. \& Smets, F. (2005). The Industry Effects of Monetary Policy in the Euro Area. The Economic Journal, 115(503), 319-342.

Rafiq, M. S. \& Mallick, S. K. (2008). The effect of monetary policy on output in EMU3: A sign restriction approach. Journal of Macroeconomics, 30, 1756-1791.

Raghavan, M. \& Silvapulle, P. (2008). Structural VAR approach to Malaysian monetary policy framework: Evidence from the pre-and post-Asian crisis periods. Paper presented at the New Zealand Association of Economics 49th annual conference, Markets and Models, 9-11 July, Wellington, New Zealand.

Ramaswamy, R. \& Sloek, T. (1998). The real effects of monetary policy in the European Union: What are the differences? IMF Staff Papers, 374-396.

Riman, H. B., Akpan, E. S. \& Offiong, A. I. (2013). Asymmetric effect of oil price shocks on exchange rate volatility and domestic investment in Nigeria. British Journal of Economics, Management and Trade, 3, 513-532.

Rodrik, D. (2007). Industrial development: some stylized facts and policy directions. Industrial development for the 21st century: sustainable development perspectives, 7-28.

Rodrik, D. (2008). Understanding South Africa's economic puzzles. Economics of Transition, 16(4), 769-797.

Sims, C. A. \& Zha, T. (2006). Does monetary policy generate recessions? Macroeconomic Dynamics, 10, 231272.

South African Government. (2016). New Growth Path, accessed on 25 http://www.gov.za/about-government/government-programmes/new-growth-path

Sousa, J. M. \& Zaghini, A. (2007). Global monetary policy shocks in the G5: A SVAR approach. Journal of International Financial Markets, Institutions and Money, 17, 403-419.

Suzuki, T. (2004). Is the lending channel of monetary policy dominant in Australia? Economic Record, 80, 145156.

Van Aarle, B., Garretsen, H. \& Gobbin, N. (2003). Monetary and fiscal policy transmission in the Euro-area: Evidence from a structural VAR analysis. Journal of Economics and Business, 55, 609-638.

Vongi, M. (2010). The Global Financial Crisis and its impact on the South African Economy. (Unpublished Master's dissertation). University of Fort Hare, Alice, South Africa.

Vonnák, B. (2005). Estimating the effect of Hungarian monetary policy within a structural VAR framework. (MNB Working Papers No. 2005/1).

Zini, M. (2008). The Impact of the Financial Crisis on South Africa. Available online at http://scholar.google.co.za/scholar?q=The+Impact+of+the+Financial+Crisis+on+South+Africa\&btnG $=\& \mathrm{hl}=$ en\&as_sdt $=0 \% 2 \mathrm{C} 5$ 